\title{
PERSEPSI DAN MINAT MASYARAKAT TERHADAP KONSUMSI SUSU
}

\author{
Erika Dewi Anggraeni*1, Syarif Imam Hidayat', Indra Tjahaja Amir ${ }^{1}$ \\ Program Studi Agribisnis, Universitas Pembangunan Nasional "Veteran" Jawa Timur \\ *e-mail: erikadewi285@gmail.com
}

\begin{abstract}
Indonesia has great potential in the development of the agribusiness sector. One of the sectors that can be developed is the livestock sector. Milk is one of the livestock products that are consumed daily by the community. In 2019, Indonesia's milk consumption was recorded at 16.23 liters/capita/year. Indonesia's milk consumption is still relatively low compared to Singapore and Malaysia. This study aims to determine public perception of milk and milk consumption, and public interest in milk consumption. Data were obtained from interviews through questionnaires and analyzed using descriptive analysis. The results showed that $65.6 \%$ of respondents chose a positive view of milk, 57.43\% of respondents had a positive view of milk consumption and $74.16 \%$ of respondents had a positive opinion of the benefits of milk. There are $40 \%$ of respondents who have a moderate purchase frequency, $73.3 \%$ of respondents have a low consumption frequency and $61.7 \%$ of respondents have a low milk consumption measure.
\end{abstract}

Keywords: Milk, Public Perception, Public Interest, Reason

\section{PENDAHULUAN}

Indonesia mempunyai potensi yang besar dalam pengembangan bidang agribisnis, hal ini dapat dilihat dari ketersediaan sumber daya yang belum dapat dimanfaatkan secara maksimal. Salah satu sektor yang dapat di kembangkan adalah sektor peternakan karena sektor peternakan ini berperan penting untuk memenuhi kebutuhan pangan hewani masyarakat. Diketahui bahwa kandungan gizi hasil ternak beserta produk olahannya mempunyai kandungan nilai gizi lebih baik dibandingkan dengan protein yang berasal dari tumbuh-tumbuhan (nabati). Serta dalam rangka mencapai tujuan pembangunan peternakan harus lebih diarahkan pada pengembangan peternakan yang lebih maju melalui penggunaan teknologi tepat guna, efisien dan produksi berkelanjutan, sehingga mampu meningkatkan pendapatan dan taraf hidup peternak. Susu merupakan salah satu produk hasil peternakan yang menjadi konsumsi sehari-hari oleh masyarakat, serta susu sangat bermanfaat bagi seluruh kalangan usia. Karena susu memiliki kandungan gizi yang lengkap dan seimbang serta susu mengandung banyak kalsium yang memiliki manfaat untuk pertumbuhan tulang dan gigi.

Tindakan konsumsi setiap hari dilakukan oleh siapapun tujuannya adalah untuk memperoleh kepuasan setinggi-tingginya dan mencapai tingkat kemakmuran dengan terpenuhinya semua kebutuhan. Sukirno (2010) menjelaskan, bahwa konsumsi rumah tangga adalah nilai belanja yang dilakukan oleh rumah tangga untuk membeli berbagai jenis kebutuhannya dalam satu tahun tertentu. Pendapatan yang diterima oleh rumah tangga akan 
digunakan untuk membeli makanan, membiayai jasa angkutan, membayar pendidikan anak, membayar sewa rumah dan membeli kendaraan. Konsumsi susu Indonesia setiap tahunnya mengalami peningkatan namun tidak diimbangi dengan peningkatan produksi susu dalam negeri, maka akan terjadi kesenjangan. Kebutuhan penduduk yang terus meningkat membuat negara akan terus berusaha untuk memenuhi kebutuhan dalam negeri. Salah satunya adalah bekerjasama dengan negara lain untuk melakukan impor susu demi memenuhi kebutuhan konsumsi susu nasional.

Menurut Badan Pusat Statistik (BPS) pada tahun 2019 konsumsi susu Indonesia sebesar 16,23 liter/kapita/tahun. Jumlah ini telah mengalami peningkatan dari tahun sebelumnya sebesar 0,20 liter/kapita/tahun. Walaupun dikatakan meningkat, jumlah konsumsi susu masyarakat Indonesia masih termasuk rendah dibandingkan konsumsi susu negara di Asia Tenggara. Negara Brunei mengonsumsi susu sebanyak 129,1 liter/kapita/tahun, Malaysia mengonsumsi susu sebesar 50,9 liter/kapita/tahun, Singapura mengonsumsi susu sebesar 46,1 liter/kapita/tahun dan Vietnam mengonsumsi 20,1 liter/kapita/tahun (Outlook Susu, 2019). Konsumsi susu di Indonesia dikatakan mengalami peningkatan setiap tahunnya, namun masih tergolong rendah di Asia Tenggara. Di Indonesia sebenarnya upaya peningkatan konsumsi susu sudah sejak lama dilakukan, salah satunya oleh Prof. Poorwo Sudarmo telah mencetuskan semboyan empat sehat lima sempurna pada tahun 1950-an. Dimana susu merupakan pelengkap kelima. Tetapi upaya yang sudah dilakukan selama ini untuk meningkatkan konsumsi susu per kapita, tampaknya masih belum memberikan hasil yang memuaskan. Hal ini dapat dilihat dari jumlah konsumsi per kapita Indonesia yang masih rendah per tahunnya dari jumlah anjuran kementerian kesehatan.

Penentuan karakteristik produk susu tersebut berdasarkan pada persepsi susu masyarakat Indonesia. Sebagian besar masyarakat Indonesia beranggapan bahwa susu merupakan produk untuk dikonsumsi oleh anak-anak dan balita sebagai diet pelengkap dengan kandungan lemak tinggi (Ahmad \& Hermiyetti 2020). Akibatnya masyarakat merasa bahwa minum susu bukanlah sebagai prioritas utama, sehingga dapat diabaikan. Masyarakat lebih memprioritaskan mengonsumsi makanan yang mengenyangkan dan lebih murah, serta sebagian masyarakat juga menilai bahwa minum susu dapat menyebabkan kegemukan sehingga harus dihindari.

Tujuan penelitian adalah untuk menganalisis persepsi terhadap susu dan konsumsi susu, serta mengetahui minat terhadap konsumsi susu di kalangan masyarakat. Penelitian ini nantinya diharapkan dapat memberikan kontribusi bermanfaat bagi industri persusuan yang membutuhkan informasi terkait konsumsi susu di kalangan masyarakat dalam menentukan strategi pemasarannya dan bagi pemerintah dalam menetapkan alat kebijakan yang lebih baik tentang konsumsi susu bagi masyarakat. Bagi konsumen, hasil penelitian merupakan informasi berharga yang dapat menjadi masukan berharga dalam mempertimbangkan mengonsumsi susu.

\section{METODE PENELITIAN}

Pengambilan data menggunakan metode survei dengan kuesioner terstruktur. Responden penelitian adalah Orang tua dengan anak usia 0-14 tahun, remaja dengan usia 15-25 tahun dan dewasa dengan usia >25 tahun. variabel-variabel yang diamati dalam penelitian ini adalah persepsi responden terhadap susu dan konsumsi susu dan minat responden terhadap konsumsi susu. Karakteristik persepsi meliputi : pandangan terhadap susu, konsumsi susu dan manfaat 
susu. Karakteristik minat meliputi: frekuensi pembelian susu, frekuensi konsumsi susu, ukuran konsumsi susu dan alasan mengonsumsi susu.

Populasi pada penelitian ini adalah masyarakat yang mengonsumsi susu, baik susu segar maupun susu kemasan (UHT, Bubuk, Kental manis). Dalam menentukan sampel, peneliti menggunakan metode Quota sampling untuk memilih responden pada penelitian ini. Penentuan besarnya jumlah responden berdasarkan kriteria yang telah ditetapkan oleh responden. Hal ini sesuai dengan pernyataan Sugiyono (2017) ukuran sampel yang layak dalam penelitian adalah antara 30 sampai dengan 500.

Data penelitian ini dikumpulkan melalui wawancara dengan menggunakan kuesioner terstruktur. Pertanyaan-pertanyaan dalam kuesioner menggunakan skala Likert untuk mendapatkan skala interval dan rasio untuk menentukan tingkatan minat konsumsinya. Analisis deskriptif dilakukan untuk menjelaskan data yang telah di dapatkan dari hasil wawancara menggunakan kuesioner.

\section{HASIL DAN PEMBAHASAN}

Tabel 1. Karakteristik Responden Penelitian $(n=60)$

\begin{tabular}{|c|c|c|c|c|c|}
\hline \multicolumn{2}{|c|}{ Karakteristik } & \multirow{2}{*}{$\begin{array}{c}\text { Jumlah } \\
20\end{array}$} & \multicolumn{2}{|c|}{ Karakteristik } & \multirow{2}{*}{$\begin{array}{c}\text { Jumlah } \\
-\end{array}$} \\
\hline Usia & $15-25 \mathrm{Th}$ & & Jenis Susu & Susu Segar & \\
\hline \multirow[t]{3}{*}{ Responden } & 26-35 Th & 39 & Yang & Susu Cair & 27 \\
\hline & $>35 \mathrm{Th}$ & 1 & Dikonsumsi & Susu Bubuk & 29 \\
\hline & & & & Susu Kental Manis & 4 \\
\hline Usia anak & $0-5 \mathrm{Th}$ & 17 & Ukuran & $<1$ gelas & 37 \\
\hline Responden & $6-14 \mathrm{Th}$ & 3 & Konsumsi & 1 gelas & 8 \\
\hline$(20$ & & & dalam satu & $\geq 2$ gelas & 15 \\
\hline Responden) & & & hari & & \\
\hline Tingkat & SMP & 1 & Pendapatan & $<\operatorname{Rp} 3.000 .000$ & 33 \\
\hline Pendidikan & SMA/SMK & 16 & & $\mathrm{Rp} 3.000 .000-\mathrm{Rp}$ & 18 \\
\hline \multirow[t]{3}{*}{ Responden } & D I/II/III/IV & 7 & & 4.500 .000 & \\
\hline & Sarjana (S1) & 34 & & $>\operatorname{Rp} 4.500 .000$ & 9 \\
\hline & Pascasarjana (S2) & 2 & & & \\
\hline
\end{tabular}

Sumber: Data Primer Penelitian, diolah 2021

Tabel 1.menunjukkan karakteristik responden penelitian, antara lain meliputi: Usia responden penelitian sebagian besar berusia 26-35 tahun, rata-rata responden memiliki anak usia 0-5 tahun. Sebagian besar responden memiliki tingkat pendidikan tamat SMA, D I/II/III/IV dan Sarjana (S1). Pada penelitian ini ditemukan bahwa tingkat. Pada penelitian ini ditemukan bahwa rata-rata responden penelitian adalah lulusan Sarjana. Jenis susu yang banyak dikonsumsi adalah susu cair dan susu bubuk. Hal ini sejalan dengan pernyataan Prastiwi dan Setiyawan (2016), yang menyatakan bahwa jenis susu cair yang paling banyak dikonsumsi oleh masyarakat perkotaan dan pedesaan adalah susu UHT yang dapat dengan mudah didapatkan dari minimarket. Ukuran konsumsi susu responden rata-rata $<1$ gelas dalam sehari. Pendapatan responden per bulan < Rp 3.000.000 lebih banyak yakni mencapai 33 responden, dibandingkan dengan pendapatan Rp 3.000.000 - Rp 4.500.000 yang hanya berjumlah 18 responden dan 
pendapatan > Rp 4.500.000 hanya berjumlah 9 responden. Hal ini menunjukkan rata-rata responden memiliki pendapatan per bulan tergolong rendah.

\section{Persepsi Terhadap Susu dan Konsumsi Susu}

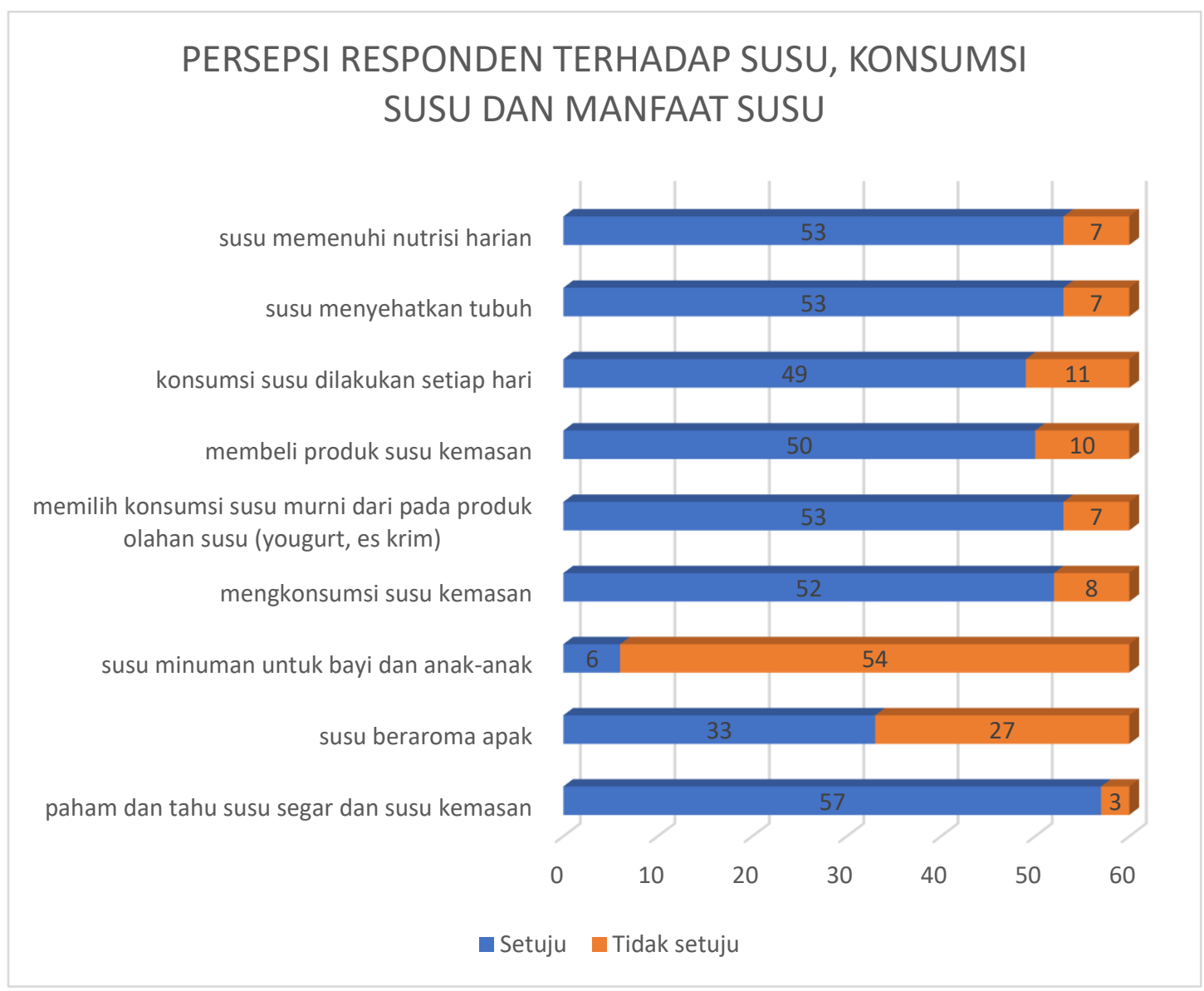

Sumber: Data Primer Penelitian, diolah 2021

Gambar 1. Persepsi Responden

Gambar 1. menunjukkan persepsi responden mengenai pandangan terhadap susu, pandangan konsumsi susu dan manfaat susu. Dari hasil penelitian menunjukkan lebih dari $70 \%$ responden menyatakan persepsi terhadap susu setuju bahwa mengetahui susu (susu segar dan susu kemasan), susu beraroma apak dan susu bukan minuman untuk bayi dan anak-anak. Persepsi mengenai pandangan konsumsi susu menunjukkan lebih dari $65 \%$ responden setuju mengonsumsi susu dilakukan setiap hari, mengonsumsi susu murni dan susu kemasan. Pada dasarnya responden lebih banyak memilih susu murni dibandingkan dengan produk olahan susu karena kandungan gizi dan nutrisi pada susu murni lebih kompleks dibandingkan produk olahan susu yang bahan dasarnya dari susu. Tingginya persepsi responden terhadap konsumsi susu kemasan dikarenakan produk susu kemasan mudah dijumpai di lingkungan masyarakat, banyak dijual di toko ataupun super market. Sedangkan alasan lain yang mendasari adalah umur simpan susu kemasan lebih tahan lama dibandingkan dengan susu segar. 
Tabel 2. Persepsi Masyarakat Terhadap Konsumsi Susu

\begin{tabular}{ccccc}
\hline $\begin{array}{c}\text { Indikator } \\
\text { Persepsi }\end{array}$ & $\begin{array}{c}\text { Orang tua } \\
\text { dengan anak } \\
\text { usia 0-14 } \\
\text { Tahun }\end{array}$ & $\begin{array}{c}\text { Remaja } \\
\text { Usia 15-25 } \\
\text { Tahun }\end{array}$ & $\begin{array}{c}\text { Dewasa } \\
\text { Usia > 25 } \\
\text { Tahun }\end{array}$ & $\begin{array}{c}\text { Rata- } \\
\text { Rata }\end{array}$ \\
\hline $\begin{array}{c}\text { Pandangan } \\
\text { terhadap susu } \\
\text { Pandangan } \\
\text { terhadap }\end{array}$ & $65,5 \%$ & $64 \%$ & $67,75 \%$ & $65,6 \%$ \\
$\begin{array}{c}\text { konsumsi susu } \\
\text { Manfaat susu }\end{array}$ & $64 \%$ & $50,3 \%$ & $58 \%$ & $57,43 \%$ \\
\hline
\end{tabular}

Sumber : Analisis Data Primer diolah, (2021)

Tabel 2. menunjukkan persentase persepsi responden terhadap karakteristik konsumsi susu, yang meliputi pandangan terhadap susu, pandangan terhadap konsumsi susu dan manfaat susu yang diukur menggunakan skala Likert. Pada indikator pandangan terhadap susu, rata-rata terdapat 65,6\% responden tahu dan kenal terhadap susu segar dan susu kemasan dan berpendapat susu bukan merupakan minuman untuk bayi dan anak-anak saja. Sedangkan untuk indikator pandangan terhadap konsumsi susu, rata - rata terdapat 57,43\% responden berpendapat bahwa konsumsi susu baik dilakukan setiap hari, memilih mengonsumsi susu kemasan (UHT, Susu Bubuk dan Susu kental manis) dan memilih mengonsumsi susu murni dibandingkan produk olahan susu (keju, yoghurt dan es krim). Terdapat rata-rata 74,16\% responden berpendapat bahwa susu dapat memenuhi kebutuhan nutrisi harian dan susu dapat menyehatkan tubuh. Hal ini sejalan dengan pernyataan Prastiwi dan Setiyawan (2016) yang menyatakan bahwa mayoritas masyarakat memiliki persepsi positif tentang manfaat kesehatan dan nilai gizi susu cair.

Hasil penelitian menunjukkan responden dengan usia dewasa > 35 tahun memiliki persepsi terhadap susu paling baik dibandingkan dengan kelompok responden yang lain yakni $67,75 \%$. Kelompok responden orang tua dengan anak usia 0-14 tahun memiliki persepsi terhadap konsumsi susu paling baik dibandingkan dengan kelompok lainnya yakni $64 \%$. Kelompok orang tua dengan anak usia 0-14 tahun juga memiliki persepsi manfaat susu paling baik dibandingkan kelompok lainnya yakni mencapai 79,5\%. Hal ini menunjukkan bahwa orang tua dengan anak usia pertumbuhan akan berpendapat bahwa susu dan konsumsi susu baik dilakukan setiap hari. Karena orang tua yang memiliki anak usia balita akan memberikan susu kepada anaknya sebagai pengganti ASI. 


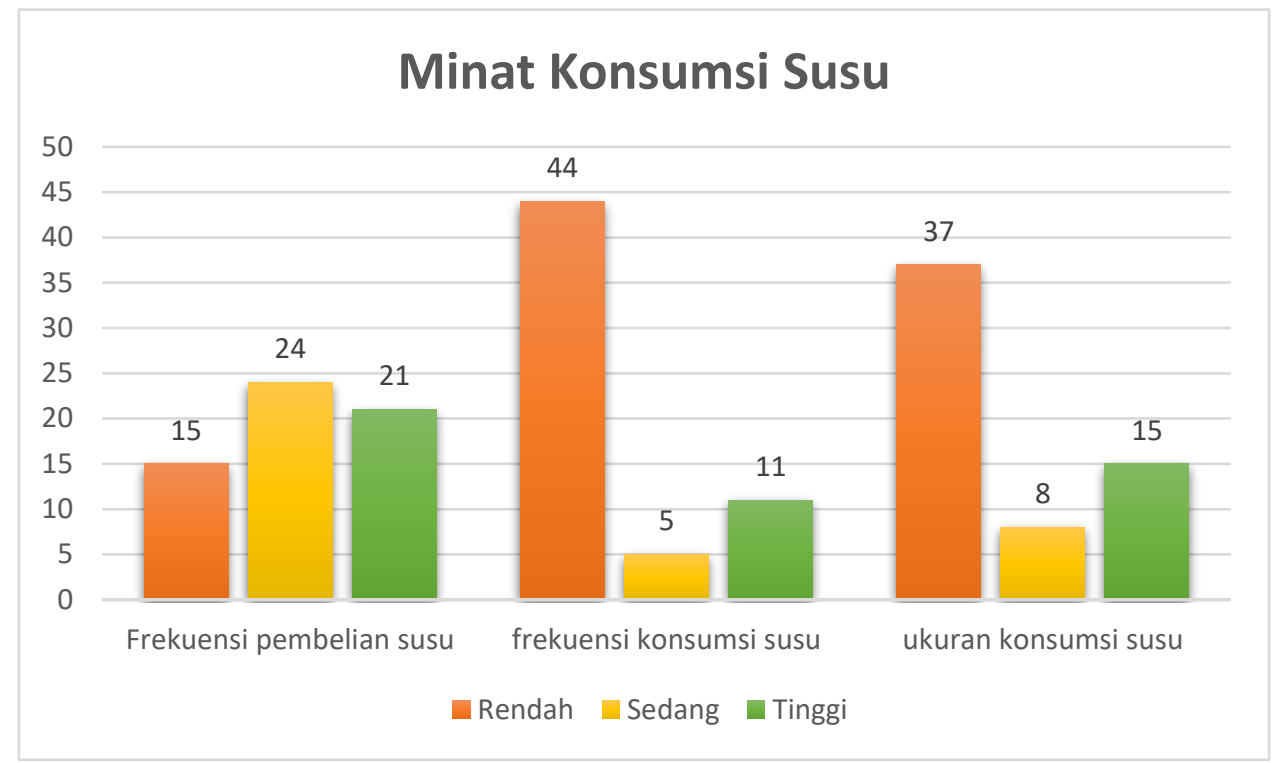

Sumber: Data Primer, diolah 2021

\section{Gambar 2. Minat Konsumsi Susu}

Gambar 2. menunjukkan hasil penelitian dari jawaban responden mengenai minat konsumsi susu dilihat dari frekuensi pembelian susu, frekuensi konsumsi susu dan ukuran konsumsi susu. Hasil penelitian menunjukkan 25\% responden memiliki frekuensi pembelian susu tergolong rendah dengan pembelian susu $\leq 1$ kali setiap bulan, $40 \%$ responden orang tergolong sedang dengan pembelian susu 2 kali setiap bulan dan 35\% responden orang tergolong tinggi dengan pembelian susu $\geq 3$ kali setiap bulan. Dari hasil penelitian ini menunjukkan rata-rata responden memiliki frekuensi konsumsi susu kategori sedang atau membeli susu 2 kali setiap bulannya. Dari hasil penelitian frekuensi konsumsi susu yang dilakukan oleh responden, 73,3\% memiliki frekuensi konsumsi rendah dengan konsumsi susu $\leq 1$ kali setiap hari, 8,3\% memiliki frekuensi sedang dengan konsumsi susu 2 kali setiap hari dan 18,4\% memiliki frekuensi konsumsi tinggi dengan konsumsi susu $\geq 3$ kali setiap hari. Hal ini menunjukkan rata-rata frekuensi konsumsi susu responden tergolong rendah dikarenakan hanya mengonsumsi susu $\leq 1$ kali setiap harinya. Hal ini sejalan dengan pernyataan Oktavia (2015), menyatakan bahwa jumlah dan frekuensi konsumsi susu secara signifikan berhubungan dengan latar belakang pendidikan dan pendapatan per bulan. Frekuensi konsumsi susu masyarakat rendah dikarenakan pendapatan yang rendah dari responden penelitian.

Hasil penelitian menunjukkan ukuran konsumsi susu yang dilakukan responden sebesar $61,7 \%$ memiliki ukuran konsumsi rendah yakni mengonsumsi susu $<1$ gelas (200 ml) dalam satu kali konsumsi, 16,7\% memiliki ukuran konsumsi sedang yakni mengonsumsi susu 1 gelas (200 ml) dalam satu kali konsumsi dan 21,6\% memiliki ukuran konsumsi tinggi yakni $\geq 2$ gelas $(200 \mathrm{ml})$ dalam 1 kali konsumsi. Dapat dikatakan bahwa rata-rata ukuran konsumsi susu responden rendah atau $<1$ gelas dalam satu kali konsumsi. Rendahnya konsumsi susu masyarakat dipengaruhi oleh pengetahuan akan manfaat dan nilai gizi susu, semakin baik pemahaman responden maka semakin baik juga frekuensi konsumsinya. Bahwa semakin tinggi tingkat pendidikan ibu maka semakin tinggi pula konsumsi susu anak (Azkiya dan Ismawati, 2016). Hal ini tidak sesuai dengan anjuran pemerintah yang tercantum dalam Peraturan Pemerintah No 41 Tahun 2004, anjuran konsumsi susu minimal 1 gelas (200 ml) setiap harinya. 
Alasan Responden Mengonsumsi Susu

Tabel 3. Tabulasi Alasan Responden Mengonsumsi Susu

\begin{tabular}{lcc}
\hline \multicolumn{1}{c}{ Alasan Responden Mengonsumsi Susu } & $\begin{array}{c}\text { Jumlah } \\
\text { Responden } \\
\text { (Orang) }\end{array}$ & $\begin{array}{c}\text { Persentase } \\
(\%)\end{array}$ \\
\hline $\begin{array}{l}\text { Menjaga keseimbangan gizi dan menambah nutrisi } \\
\text { tubuh }\end{array}$ & 34 & $57 \%$ \\
Menjaga kesehatan dan daya tahan tubuh & 10 & $17 \%$ \\
$\begin{array}{l}\text { Pengganti sarapan/ penunda lapar } \\
\text { Memperlancar asi }\end{array}$ & 13 & $22 \%$ \\
Menjaga kesehatan janin & 2 & $3 \%$ \\
\multicolumn{1}{c}{ Total } & 1 & $1 \%$ \\
\hline
\end{tabular}

Sumber: Data Primer diolah, 2021

Dari hasil tersebut menunjukkan bahwa jenis konsumsi susu yang paling banyak di konsumsi oleh responden penelitian adalah susu bubuk, dimana konsumen tertinggi susu bubuk adalah anak-anak usia balita. Penelitian yang dilakukan untuk mengetahui persepsi dan minat konsumsi susu pada masyarakat di pengaruhi oleh berbagai alasan. Hal ini peneliti mengelompokkan alasan responden mengonsumsi susu menjadi enam kategori yang dapat dilihat pada Tabel 3. Berdasarkan hasil tersebut dapat disimpulkan bahwa sebagian besar responden mengonsumsi susu dikarenakan untuk menjaga keseimbangan gizi dalam tubuh dan juga untuk menambah nutrisi yang tidak didapatkan dari makanan lain. Selanjutnya responden memiliki alasan mengonsumsi susu dikarenakan untuk menjaga kesehatan tubuh dan sebagai sarapan atau penunda lapar. Hal tersebut merupakan alasan responden yang banyak diungkapkan sebagai alasan mengonsumsi susu.

\section{KESIMPULAN DAN SARAN}

\section{Kesimpulan}

Adapun kesimpulan yang diperoleh dari penelitian mengenai persepsi dan minat masyarakat terhadap konsumsi susu adalah sebagai berikut:

1. Tercatat terdapat $65,6 \%$ responden memilihi pandangan positif terhadap susu yang dilihat dari persepsi responden tahu dan kenal susu segar dan susu kemasan dan berpendapat bahwa susu bukan minuman untuk bayi dan anak-anak saja. 57,43\% responden memiliki pandangan positif terhadap konsumsi susu yang dilihat dari persepsi responden tentang mengonsumsi susu baik dilakukan setiap hari dan lebih memilih mengonsumsi susu murni dibandingkan susu kemasan dan terdapat $74,16 \%$ responden berpendapat positif terhadap manfaat yang dikandung oleh susu yang dilihat dari persepsi responden bahwa susu memiliki banyak manfaat bagi tubuh bila dikonsumsi. 
2. Tingkat minat konsumsi susu yang dilakukan oleh masyarakat masih tergolong sangat rendah. Tercatat $40 \%$ responden memiliki frekuensi pembelian tergolong sedang dengan pembelian susu 2 kali setiap bulan. Terdapat 73,3\% responden memiliki frekuensi konsumsi rendah dengan konsumsi susu $\leq 1$ kali setiap hari. $61,7 \%$ responden memiliki ukuran konsumsi susu tergolong rendah yakni mengonsumsi susu $<1$ gelas (200 ml) dalam satu kali konsumsi.

3. Berdasarkan hasil tersebut dapat disimpulkan bahwa sebagian besar alasan responden mengonsumsi susu dikarenakan untuk menjaga keseimbangan gizi dalam tubuh dan juga untuk menambah nutrisi yang tidak didapatkan dari makanan lain. Selanjutnya responden memiliki alasan mengonsumsi susu dikarenakan untuk menjaga kesehatan tubuh dan sebagai sarapan atau penunda lapar.

\section{Saran}

Saran dan masukan dari penelitian persepsi dan minat masyarakat terhadap konsumsi susu adalah sebagai berikut: Program yang dapat dilakukan adalah dengan cara memberlakukan kebiasaan minum susu sejak usia dini. Program pemerintah yang dapat dijalankan adalah minum susu setiap pagi bagi siswa sekolah. Hal ini dapat meningkatkan minat konsumsi susu melalui kebiasaan sejak usia dini.

\section{DAFTAR PUSTAKA}

Ahmad, I. \& Hermiyeti. (2020). Analisis Produksi Dan Konsumsi Susu Di Indonesia (Analysis of Milk Production and Consumption in Indonesia). Semiloka Nasional Prospek Industri Sapi Perah Menuju Perdagangan Bebas. 413-419. Puslitbang Peternakan, Prosiding, 7. http://peternakan.litbang.deptan.go.id/fullteks/lokakarya/loksp08-58

Azkiya, Saila \& Ismawati, R. (2016). Faktor-Faktor Yang Mempengaruhi Tingkat Konsumsi Susu Anak Sekolah Dasar Madrasah Ibtidaiyah Fie Sabilil Muttaqien Tempurejo Kabupaten Ngawi. E-Journal Boga, 5(1), 118-123. https://jurnalmahasiswa.unesa.ac.id/index.php/jurnal-tata-boga

Badan Pusat Statistik. (2019). Konsumsi Susu Indonesia 2019. Jakarta: Badan Pusat Statistik

Kementrian Pertanian. (2019). Outlook Susu. Jakarta: Kementrian Pertanian Republik Indonesia.

Octavia, S. A. (2015). Pengaruh Faktor Sosial Ekonomi Terhadap Perilaku Konsumsi Susu Pada Remaja. Journal Majority, 4 (November), 89-92. http://juke.kedokteran.unila.ac.id/index.php/majority

Prastiwi, W. D., \& Setiyawan, H. (2016). Perilaku Konsumsi Susu Cair Masyarakat Di Daerah Perkotaan Dan Pedesaan (Milk Consumption Behavior of Urban and Rural Communities). Agriekonomika, $5(1)$

41. https://doi.org/10.21107/agriekonomika.v5i1.996 
Prastiwi, W. D., \& Setiyawan, H. (2016). Persepsi Konsumsi Susu Cair Masyarakat Di Daerah Perkotaan Dan Pedesaan (Perception Of Urban And Rural Communities In Consuming Fluid Milk). Agromedia, Vol 34 No I: 27-36. https://jurnalkampus.stipfarming.ac.id/index.php/am

Sugiyono. (2017). Penelitian Kuantitatif, Kualitatif dan R\&D. Bandung: Alfabeta. CV.

Sukirno, Sadono. (2010). Mikro Ekonomi Teori Pengantar. Edisi Ketiga. Jakarta: Rajawali Pers. 